\title{
Interventions in Urban Geopolitics
}

${ }^{1}$ Rokem, J. and Fregonese, S.; ${ }^{2}$ Ramadan, A. and Pascucci, E.A.; Rosen, G. and Charney, I.; Paasche, T.F. and Sidaway, J. D.

These interventions in urban geopolitics recognise that it is timely to develop a research agenda that reinforces, broadens and regenerates this field, bridging the disciplines of political geography, urban studies, planning and architecture in renewed ways. Tracing the "changing cartography of danger" (Dalby, 2010: 285) in the post- 9-11 world, critical geopolitics have posited a reformulation of geopolitics "from a state-towards a city-centric focus" (Agnew, 2003: 10) where micro-sites and urban battlefields ought to be given as much thought as more conventional macromilitary reasoning (Dalby, 2010). These ideas have shaped much of what we frame here as an emerging 'urban geopolitical turn' (Graham, 2004a, 2010; Sidaway, 2009; Fregonese, 2009, 2012; Yacobi, 2009; Rokem \& Boano, In Press).

Urban geopolitics has traditionally stemmed from two main and intrinsically diverse strands of research. Authors in both strands have employed the term "urban geopolitics" in more or less

\footnotetext{
${ }^{1}$ Interventions editors and authors:

Corresponding author and editor: Dr. Jonathan Rokem, University College London, UK. (j.rokem@ucl.ac.uk) Co-author and editor: Dr. Sara Fregonese, University of Birmingham, UK.

${ }^{2}$ Contributing authors:

Dr. Adam Ramadan, University of Birmingham, UK and Dr. Elisa Pascucci, University of Tampere, Finland. Dr. Gillad Rosen, Hebrew University of Jeruaslem, Israel and Dr. Igal Charney, University of Haifa, Israel. Dr. Till F. Paasche, Soran University, Kurdistan Region, Iraq and Prof. James D. Sidaway, National University of Singapore.
} 


\section{Rokem et-al (2017) Intervention in Urban Geopolitics, Political Geography Journal}

Pre-publication version (Accepted $2^{\text {nd }}$ April 2017)

different ways, some engaging with it more explicitly than others, but all have attempted to conceptualise and produce empirical knowledge about the complex and intimate relations between urban space and diverse and multi-scalar political geographies. Here, geopolitically charged urban sites act as connectors between localised experiences of violence and wider geopolitical processes, a link already theorized - albeit not in an explicitly urban fashion - by feminist geopolitics (Hyndman, 2004; Pain \& Smith, 2008; Smith, 2012). The first research strand, focusing on the militarization of urban space, surveillance and security (Graham and Wood 2003; Coaffee, 2004; Graham, 2004a, 2010), the performative spaces and geographical imaginations of late-modern war (Gregory, 2016; Ramadan, 2009) and the vertical/aerial geometries of urban and asymmetric conflicts (Weizman, 2007; Gregory, 2011; Elden, 2013) has led to a deeper scrutiny of cities and their encounters with and endurance of material damage and targeted violence. Second, in the past two decades, a fast evolving strand of research has focused more specifically on urban conflicts within ethno-nationally contested cities, especially in relation to the role of planning and architecture (see, e.g. Hepburn 2004; Fregonese 2009; Fregonese, 2012; Anderson, 2010; Pullan 2011; Bollens, 2012) as well as to the role of "myriad of urban networks and infrastructures that are not bound by official planning procedures" (Leshem, 2015: 35) through which cities experience ethno-national conflict.

Although the architecture of cities has historically been both medium and target of political violence (Hirst, 2005), as researchers and residents in a predominantly urbanized world we can no longer ignore expanding violence, disaster, and division in cities. Urban environments across the planet are becoming hypersecuritised and yet insecure. The Paris and Brussels terrorist attacks in 
November 2015 and March 2016 and subsequent citywide lock-downs have questioned the state of security of European capital cities in the wake of new types of violent urban emergencies. Meanwhile, armed police in the streets of London is being increased by $20 \%$ to make the environment "hostile" for potential attackers (BBC News, 2016); airports, hotels, shopping malls and concert venues from Germany to Sinai, from France to Tunisia and the Somali coast, have become predominant soft targets. Entire cities are starved and sieged throughout Syria. Conflict and violence in all their degrees and nuances have become a political and humanitarian concern that is predominantly urban and affecting the everyday life of city dwellers. There is an increasing need, therefore, to critically re-examine and establish urban geopolitics as a necessary subdisciplinary lens through which to make sense of the impact these grand challenges have on the global urban present.

As a result of these shifts in global and local forces, the political geographies of cities are being reshaped, frequently in unpredictable ways, their populations coming together or becoming polarised with often un-ordinary and underexplored patterns. One question remains open: whether it is time to challenge the canonical differentiation between urban phenomena of socio-economic spatial segregation, socio-political division, and of militarized urban conflict, and - ultimately - the very distinction between 'conflict cities' and more peaceful ones (Rokem, 2016a: 406). As such, this intervention suggests that Urban Geopolitics ought to move beyond its currently restricted focus on cities as direct targets of terror and violence, as fully militarized grounds of open conflict, or as vertical/aerial geometries of urban asymmetric warfare (Harries 2015; Rosen \& Chareny, 2016). 
For this purpose, we present here five renewed themes, to a certain extent interrelated and overlapping, aimed at opening up the scope of urban geopolitics to account for a number of urban grand challenges of the $21^{\text {st }}$ century. These are: (1) Ordinary urban geopolitics; (2) Towards domestic urban geopolitics; (3) Urban geopolitics of refuge; (4) Geopolitics of Urban Verticality: Beyond Unidimensionality; (5) a concluding contribution; The urban and the geopolitical as categories of theory and practice: front-line reflections. While the first four contributions serve as anchor points to step beyond the technocentric, militaristic and ethno-national approaches that have been at the centre of urban geopolitics' conceptualisations and empirical case studies so far, the fifth text moves us back from the more ordinary and everyday domains to the militaristic sphere of contemporary urban warfare and its brutal consequences on the ground in Iraq and Syria; in so doing, it conveys some broader observations deriving from a first hand - albeit clearly partial account of the urban battlefields that nowadays are informing much of the geopolitical thinking about that portion of the Middle East. Through these five contributions, we propose a way to start re-engaging in a critical reading of contestation in cities, and specifically towards a renewed understating of urban geopolitics that accounts for the postcolonial, ordinary, domestic, embodied and vertical dimensions in order to better comprehend recent global shifts and their urban challenges. 
Rokem et-al (2017) Intervention in Urban Geopolitics, Political Geography Journal

Pre-publication version (Accepted $2^{\text {nd }}$ April 2017)

\section{Ordinary Urban Geopolitics}

\section{Dr. Jonathan Rokem, University College London, UK.}

The compositional, messy, uncontrollable and recombinant nature of the present urbanism, and the differential knowledge at play in the construction of the urban, is anything but straightforward (Peck, 2015:161).

A growing concern has developed among urban studies scholars regarding the need to rethink the discipline, from theoretical and epistemic assumptions, to methodological and ethical issues (Amin \& Thrift, 2002; Allegra at el, 2013; Peck, 2015; Robinson, 2006, 2016; Roy 2016). This on-going debate, however, has not yet investigated geopolitics and its relevance to urban studies and planning in any significant detail. This brief intervention aims to advance the cross-disciplinary field of urban geopolitics, by bringing geopolitics into the mainstream of urban studies and planning research. From a planning standpoint, there is a need to enhance our understanding of cities as significantly shaped by everyday manifestations of political faultlines, and of how this affects a multiplicity of outcomes across geographical scales.

The geographies of cities are restructuring, frequently in unpredictable ways, with their urban populations coming together and becoming polarised within often-underexplored migration, segregation and mobility patterns (Rokem \& Vaughan, 2017). The emerging 'urban geopolitical turn' (Rokem \& Fregonese, this issue; Rokem \& Boano, In press) has so far predominantly engaged with extreme urban combat, and the total breakdown and rapture of urban systems during conflict (Graham, 2004a, 2010; Weizman, 2007; Gregory, 2016). While these debates have been significant 
in bridging the field of geopolitics and its traditional focus on national and regional territorial conflicts to a more urban scale (Agnew, 2003; Fregonese, 2012), they have generally overlooked the more ordinary everyday understandings of urban contestation, segregation and mobility.

Conceptualising urban geopolitics beyond the total rapture and breakdown of municipal systems and cities as a war-torn battlefields, allows developing a renewed look more attuned to the everyday manifestations across the messier ordinary processes of segregation and mobility and their connection to questions of migration and refuge (see: Pascucci \& Ramadan, this issue). In the last few decades, urban protest in several countries worldwide has augmented to new summits as a result of the expanding and deepening neo-liberal inequalities and ethno-racial contestation of the urban sphere. Some prominent examples include the Afro-American urban riots in the 1960s and the French early 2000s North African immigrant riots in the banlieues. These events among others have reconstructed and divided urban territory, producing patterns of contested socio-spatial formations and creating new local geopolitical trajectories and zones for the urban outcasts (Wacquant, 2008). The present international geopolitical turmoil in the Middle East and Africa has intensified these processes shaping large-scale forced migration and growing local opposition and dissent (Allegra at el, 2013). Further attention needs to be placed on the impact of the current unstable geopolitical conditions worldwide and their affect on the ordinary daily life and (lack of) planning to accommodate growing tensions in cities.

Segregation and mobility are proposed here as two overarching themes to capture the more openended nature of ordinary and often unplanned and informal urban geopolitical processes. More 


\section{Rokem et-al (2017) Intervention in Urban Geopolitics, Political Geography Journal}

Pre-publication version (Accepted $2^{\text {nd }}$ April 2017)

than emphasizing a set of given qualities associated with the urban environment, segregation and mobility suggest ways to explore everyday movements with a geopolitical significance at the urban and local scale. In other words, while segregation distinguishes geographically between different groups, without mobility mixing of different groups cannot occur (Rokem \& Vaughan, 2017). This enables us to delineate the contours of the city as a meaningful site to analyse mobility and borders between different groups, with more attention given to the 'planning politics nexus'; the relation between planning and politics, as a non-hierarchical set of interactions, negotiated within the specific historical, geographical, legal and cultural context (Rokem \& Allegra, 2016).

Urban segregation is regarded as a universal academic framework relating to socio-economic, ethnic and political divisions in cities (Nightingale, 2012). It contains a wide spectrum of theoretical and conceptual principles, ranging from the effects of neo-liberal globalisation on social inequalities in cities (Smith, 2002; Marcuse \& van Kempen, 2002), the injustices of state-led spatial planning and housing policies (Sandercock, 2003; Lees, 2012) and how ethnicity and race affect the more longterm formation of spatial and social segregation in cities (Marcuse, 1997; Musterd \& Ostendorf, 2013). Historically, debates surrounding urban segregation stem from the Chicago School's biological model of the city (Park et al, 1925) and the North American racial typology of the ghetto (Marcuse, 1997, 2006; Wacquant, 2008, 2016). Its U.S. origins are one of the main reasons that the subject (at least in the English language literature) has historically been dichotomized as a (literally) black/white race-based urban problem, rather than the more multi-faceted ethno-racial, economic and spatial condition that manifests itself worldwide (Nightingale, 2012). This is also manifested in 
the recent call to pay more attention to intersectionality of multiple identities within urban segregation research (Vaughan \& Arbaci, 2011).

Literature on urban segregation (Smets and Salman, 2008) and contested cities (Hepborn, 2004; Bollens, 2012) tends to overlook mobility and its important role in fostering co-presence leading to interactions within cities. "[I]t has long been recognized that mobility or mobilities are both generating and an outcome of inequalities and exclusion" (Kwan \& Schwanen, 2016: 248) As such, the availability of public transportation and personal mobility has critical implications for access to employment and it affects housing and education opportunities. Immobility, or being trapped within one's neighbourhood, constitutes one of the main causes of social exclusion (Massey, 1994; Leitner et al, 2008). Urban segregation should be viewed as more multifarious and complex, suggesting it is simultaneously a political, social, economic ethnic and racial artefact of an individual's potential mobility in the city. Segregation alone is not necessarily a problem and can be seen more positively as spatial congregation, but overcoming a combination of segregation and immobility is an urgent challenge in seeking spatial and social justice (Rokem \& Vaughan, 2017). Increased segregation and immobility lead to urban generated violence and fear entangled with processes of societal change producing new forms of exclusion in cities. Impoverished and spatially disconnected neighborhoods in European cities, especially in the North are becoming widespread. Examples such as Fittja in the South and Rinkeby North Stockholm, both neighborhoods with more then 90 percent of the population born abroad (Rokem, 2016b). 
It is important to bring geopolitics into the mainstream of urban studies to expose the impact of daily events on long-term planning processes negotiated within specific historical, geographical, legal and cultural context. Ordinary urban geopolitics is suggested as a more open-ended framework covering segregation and mobility across an expansive range of cities. Through this lense, cities can be studied as both sites of division and rising ethno-religious politics, and as places of opportunity for the emergence of new political arrangements, enabling the reconstruction of citizenship (Holston, 2008) and fostering local ethnic minority integration. Bringing geopolitics into the mainstream of urban studies becomes critical in an era of growing neo-liberalization, ethno nationalism and international migration, where urban geopolitics can be a practical lens to encapsulate recent shifts in the contemporary urban present across a multitude of continents and geographical scales. 
Rokem et-al (2017) Intervention in Urban Geopolitics, Political Geography Journal

Pre-publication version (Accepted $2^{\text {nd }}$ April 2017)

\section{Towards Domestic Urban Geopolitics}

\section{Dr. Sara Fregonese, University of Birmingham, UK.}

As the bombs stirred the ground and the shrapnel clattered down the road we fought a quiet battle of cunning for the bedclothes. Feet touched faces, arms swung across chests, elbows elbowed; snores bubbled and spluttered to be silenced by ostensibly accidental blows; fragments of wild dream-talk escaped from the depths of our private lives. (Lambert, 1965, p. 57)

The last decade has proliferated with interdisciplinary research into the links between conflict, urban space and infrastructure (Allegra, Casaglia, \& Rokem, 2012; Bollens, 2012; Brand \& Fregonese, 2013; Coward, 2009; Pullan, Misselwitz, Nasrallah, \& Yacobi, 2007; Pullan, 2011; Weizman, 2007; Yiftachel, 2006). Particularly, the sub-discipline of urban geopolitics (Demarest, 1995; Fregonese, 2009, 2012; Graham, 2004a, 2009; Ramadan, 2009; Yacobi, 2009) has extensively analysed "the effects of geopolitical events upon the practices of everyday urban life" (Yacobi \& Pullan, 2014: 516). However, urban geopolitics and wider geographies of urban conflict have almost solely focused on public and/or exterior urban spaces and buildings (Rosen \& Charney, 2016), administrative and economic complexes (Tyner, Henkin, Sirik, \& Kimsroy, 2014), transport and mobility infrastructure (Baumann, 2015; Pullan et al., 2007), city centres (Nagel, 2002), markets (Pullan, 2006), religious and cultural heritage (Coward, 2002), shopping malls and hotels (Brand \& Fregonese, 2013; Fregonese \& Ramadan, 2015; Morrison, 2016). Geographers have explored the domestic in conflict through the dramatic cases of gender roles in combat (Dowler, 1998); violent tactics linking international warfare and domestic violence (Pain, 2015); the shaping of "extreme 


\section{Rokem et-al (2017) Intervention in Urban Geopolitics, Political Geography Journal}

Pre-publication version (Accepted $2^{\text {nd }}$ April 2017)

geographies of home" (Brickell, 2012); domestic practices within state power technologies (Ginn, 2012). However, the everyday and micro-spatialities of domesticity in urban conflict is missing from the urban geopolitics research agenda.

This is surprising as, for example, feminist approaches to geopolitics have long acknowledged actually in parallel to urban geopolitics' emergence - that “[p]eople's bodies, homes, communities, and livelihoods have become the battlefields of contemporary conflict"(Hyndman, 2004: 319). Rethinking normative notions of scale and security, feminist geopolitics trace connections between intimate spaces, violence and wider (geo)political struggles (Hyndman, 2001, 2004; Pain \& Smith, 2008). Furthermore, similarly to urban geopolitics' caution against seeing cities as machines of positive progress, but rather as socio-materially connected with violence and militarism (Graham, 2004a), feminist geopolitics also unsettles the notion of home "as an universally experienced site of positive belonging" (Brickell, 2012: 575) and highlights its politically charged nature.

A conceptual and methodological bridge between urban geopolitics and feminist geopolitics, (including critical geographies of home), is therefore needed. Taken together, these literatures allow developing an overdue understanding of how two politically crucial spheres of urban life the public (polis) and the domestic (oikos) - become intimately connected with war and shape each other through it, both as political epistemes (Agamben, 2015; Loraux, 2006) and physically (Davie, 1983). More specifically, this bridge allows understanding the daily and grounded mechanisms of domesticity in conflict, "what it means to dwell in the context of warfare" (Katherine Brickell, 2012: 577; Nowicki, 2014), while going beyond predominant accounts of total destruction of home 
Rokem et-al (2017) Intervention in Urban Geopolitics, Political Geography Journal Pre-publication version (Accepted $2^{\text {nd }}$ April 2017)

(Abujidi, 2014; Porteous \& Smith, 2001), and instead engaging with usually overlooked banal domestic spatialities and practices (Harker, 2009, 2011).

I suggest two paths towards a domestic urban geopolitics. The first explores the mutual shaping of protracted urban conflict and domesticity: how residents physically alter homes during conflict and how these alterations in turn shape new domesticities. The majority of urban geopolitics accounts of house destruction (especially in Israel/Palestine) centre on attack mechanisms against the outer infrastructure (Graham, 2004b; Weizman, 2007). How does, instead, urban conflict interact with everyday interior domestic spaces, how do people reshape them and reassign functions during conflict? How and where is domesticity (re)created during urban conflict? Urban geopolitics ought to extend its enquiry onto the specific and often unique practices, spatialities and artefacts emerging from domestic dwelling during conflict. This allows not only to ground the everyday mechanisms of geopolitics, but also to politicise the domestic spaces that produce them.

The second path focuses on the role of domestic space on urban politics, during and post-conflict. In Cyprus, home dwelling is a key component of territorial division and potential reunification: abandonment, takeover and treatment of homes and even artefacts inside homes during partition and population exchanges (Navaro-Yashin, 2012; Papadakis, 2005) are tightly entangled with the wider geopolitics of the conflict. Cold War domestic technologies are products of post-WW2 Western geopolitical anxieties and wartime technologies re-geared for peace (Castillo, 2010; Colomina, 2007; Daniel, 2015), as well as sites for new practices connecting domestic space to wider urban (geo)politics: drills, nuclear sheltering, behavioural advice from state departments and 
so on. More research is needed, though, on the links between domesticity and the urban politics of late-modern conflict (civil wars, asymmetric wars, and siege) During and after conflict, homes can become arenas for private political negotiations (Nicosia); part of wider technologies of state control (Dowler, 2001); fortified residences-cum-party headquarters impacting on urban mobility and safety (Fawaz, Harb, \& Gharbieh, 2012) and at odds with the rest of the urban fabric (Donia, 2005).

Armed conflict engulfs every sphere of urban life. The opening quote illustrates the corporeal effect of WW2 on one British family's domesticity, while attempting to sleep inside the Morrison table, a metal cage designed as a table, and converting into raid shelter. Urban geopolitics presents a research gap in the study of the mutual effects between war and interior domestic spaces. Bridging urban geopolitics with feminist geopolitics and critical geographies of home, opens a double path towards a domestic urban geopolitics. The first invites to explore the mutual shaping of protracted urban conflict and domesticity, the second follows the role of domestic spaces in the wider urban (post-)conflict politics. The urban is currently a paramount arena of humanitarian concerns from conflict to refugeeness (Pascucci and Ramadan, this issue. Domestic urban geopolitics, strong of urban geopolitics' deconstruction of the daily workings of war in cities, and of feminist geopolitics' charting connections between home and the geopolitical, creates new knowldge around the daily practices and needs of people dwelling amidst war, and the spatial politics of the (post-)conflict city. 
Rokem et-al (2017) Intervention in Urban Geopolitics, Political Geography Journal

Pre-publication version (Accepted $2^{\text {nd }}$ April 2017)

\section{Urban Geopolitics of Refuge}

Dr. Adam Ramadan, University of Birmingham, UK and Dr. Elisa Pascucci, University of Tampere, Finland.

We live in times of unprecedented human displacement. 65.3 million people have been forcibly displaced from their homes worldwide; of these, 21.3 million are refugees, over half of whom are children (UNHCR, 2016a). While EU member states received more than 1.25 million asylum applications in 2015, the greatest burden of the current crisis is borne by states in the global south, with Lebanon and Pakistan hosting more than 1.5 million refugees, and Turkey over 2.5 million.

Humanitarian protection of refugees has traditionally taken place in refugee camps, spaces of 'care and control' (Malkki, 1992: 34) through which refugees are managed, contained and separated from the space of the host state. Camps are usually constructed outside or on the outskirts of cities, but even fully urban camps (see Martin, 2015) are set apart from their contexts, 'impinging upon but never truly integrated with the city' (Ramadan, 2013: 74). This separation is located in the exceptional structures of sovereignty and governance in camps, the networks of social and institutional relations that place refugee communities within a transnational social, political and cultural milieu, and the constrained temporalities of camps that are permanently temporary (Ramadan, 2013). But even as the Syrian refugee crisis has led to the construction of large camps such as Zaatari camp in the Jordanian desert, $90 \%$ of those displaced by the war in Syria are not residing in camps. In 2015, 60\% of all refugees under UNHCR (United Nations High Commissioner 
for Refugees) protection were in urban areas - up from $42 \%$ in 2008 - of whom $99 \%$ were residing in individual private accommodation (UNHCR, 2016b).

Cities as spaces of refuge is not a new phenomenon. At the end of the seventeenth century, for example, 5\% of London's population were Huguenot exiles from France (Gwynn, 1983), concentrated particularly around Spitalfields which in the twentieth century became home to waves of Jewish refugees then Bangladeshi migrants (Kershen, 2005). However, cities are becoming increasingly central to the experiences and governance of refugees and human mobility, and the question of refugees must take a central place in a renewed urban geopolitics agenda. The 'prominent silence' (Sanyal, 2014: 558) on refugees in urban geographies is being overcome by several interrelated strands of research. Urban scholars and political geographers have critically interrogated the relations between cities and refugee camps in the Global South, expanding a theoretical horizon often limited by narrow readings of biopolitics and spaces of exception (Fawaz, 2016; Martin, 2015; Sanyal, 2012). In European and North-American contexts, recent analyses have explored the re-scaling of migration control and refugee governance at the city level (Varsanyi, 2008; Walker \& Leitner, 2011), and the emergence of cities as spaces of shelter, refuge and 'sanctuary' (Darling, 2010; Ridgley, 2008).

Building upon this work, in this intervention we argue for an urban geopolitics of refuge that places questions of refugees and forced migration at the heart of today's urban experiences, struggles and politics. Recent events, initiatives, and dynamics both in Europe and the global south highlight the potential and urgency of this project. In this moment of mass displacement, new relations of 
solidarity and hospitality are being forged and new infrastructures of refuge assembled, opening up new political possibilities for refugees and the cities where they live.

The mass migration and refugee crisis affecting Europe has generated outright political hostility and a resurgence of nationalist and far right parties across the continent, with calls for international border closures, patrols, and walls. At the same time, it has generated new forms of solidarity and hospitality: from citizens welcoming refugees at railway stations to the proliferation of squats in which migrants and refugees live and mobilize politically alongside locals (Belloni, 2016), the ethical and political potential of hospitality is transformative for hosts and guests, and for cities themselves. Refugees can extend welcome too: at the Magdas Hotel in Vienna, refugee employees welcome tourists to their adopted city (Rose, 2016; see also Ramadan, 2008). The repurposing of hotels as refugee and asylum seeker accommodation highlights the overlaps between the geopolitics of refuge and tourism (Fregonese \& Ramadan, 2015; Squire, 2016; Williams \& Hall, 2000), as well as the heterogeneity of emerging urban infrastructures and practices between hospitality as 'sharing the city as common space' and refuge as shelter created 'in the absence of hospitality' (Agier, 2012: 266). As Darling (2010: 133) has argued, the ethics and politics of a geographical agenda focused on the city as a space of sanctuary 'pose(s) the central question of a relational spatial politics, of how best to negotiate the spatial juxtapositions of living with others, and the influence of others, both 'within' and 'beyond' the city'. If heterogeneity is the defining characteristic of the urban (Coward, 2007; Wirth, 1938), then such projects and struggles go to the heart of what a city is and can be.

In these emerging infrastructures, human sociality and political agency are embedded in materiality and forms of incremental presence. In cases of long-term refugee displacement, the very material 
fabric of camps and other spaces of refuge are assembled incrementally - tents replaced with corrugated iron replaced with concrete; shelters and rooms adapted and remade - while the slow accumulation of experiences and memories also builds up a sense of place and meaning (Ramadan, 2010: 50-51). Relations with neighbours and host communities, and alliances forged to find responses to infrastructural crises in housing, transportation or connectivity, can carve out new spaces of belonging at the micro-local scale. Material precariousness and disrupted temporalities such as those associated with lengthy asylum procedures, or laborious daily practices of mobility and care - might therefore facilitate, rather than threaten, coexistence (Pascucci, 2016). Through such practices of urban dwelling characterised by precarious informality - makeshift, marginal, transient and provisional - political communities are built through everyday sociality and care.

This 'subaltern urbanism' (Vasudevan, 2015: 354), however, is also increasingly ground for policy intervention and attempts at refugee control. UNHCR's Emergency Handbook sees 'dispersed settlements', such as community shelters, networks of hospitality, or rent accommodation, as opportunities for greater affordability, flexibility and capacity for fostering independence (Pascucci forthcoming). In a time of shrinking budgets for direct humanitarian assistance in the south and welfare states in the north, informality is effectively treated as a resource for self-reliance promotion, while community-based networks of support become a source of resilience and substitute for traditional infrastructures of relief, such as the emergency shelters provided in camps (Pascucci, forthcoming, see also Fawaz, 2016). By promoting the integration of displaced persons in the urban fabric of first countries of asylum, UNHCR also acknowledges and normalizes a new temporality of refuge, in which protracted displacement has become the norm, rather than the exception. The constrained temporalities of transient camps are thus being extended to life in 


\section{Rokem et-al (2017) Intervention in Urban Geopolitics, Political Geography Journal}

Pre-publication version (Accepted $2^{\text {nd }}$ April 2017)

cities. As attempts at governing displacement through urban adaptability, these dynamics are essential to the broader geopolitics of refuge. However, they do not erase the political potential that living together in cities entails, and are increasingly contested by refugees themselves through collective political mobilization (Moulin \& Nyers, 2007; Pascucci, Forthcoming).

The world is in the midst of an unprecedented refugee crisis. That crisis is increasingly urban, and marked by multi-scalar connections between the global dynamics underpinning the political geographies of displacement and the shifts in international humanitarian paradigms, and the microgeographies of solidarity and adaptability in cities. These connections at multiple scales between different geographies of violence and coexistence are what makes the urban condition of refugees a geopolitical question. With a focus on urban heterogeneity and modalities of sharing, hosting and caring, studying these new spaces of refuge is essential for 'opening up the scope' of urban geopolitics to the spatialities and temporalities of forced displacement. In doing so, we must not simply reproduce the epistemologies of 'informality' that underpin the policing of urban poverty and marginality, but remain attentive to the ways the government of displacement subsumes and institutionalizes urban coexistence, and attempts to control the contentious consequences of protracted displacement. Refuge is today a heterogeneous space of struggle where solidarities, political mobilization, biopolitical control, socio-economic marginality, infrastructural precarity, and new forms of racialized and nationalist violence converge. The new geopolitics of refuge emerging in our cities are thus not only fragile ways of living, but also and most importantly transient spaces of struggle. 
Rokem et-al (2017) Intervention in Urban Geopolitics, Political Geography Journal

Pre-publication version (Accepted $2^{\text {nd }}$ April 2017)

\section{Geopolitics of Urban Verticality: Beyond Unidimensionality}

Dr. Gillad Rosen, Hebrew University of Jeruaslem, Israel and Dr. Igal Charney, University of Haifa, Israel.

Fifteen year ago, terrorists hijacked and rammed jetliners into major symbols of American economic supremacy, military force, and political power. New York City's iconic Twin Towers, an epicenter of international commerce and American capitalism, were obliterated in the 9/11 attacks, while the Pentagon, an archetypical groundscraper home to the nation's Department of Defense, suffered severe damage. These cataclysmic events striking at the heart of the urban landscape, coupled with the proliferation of urban warfare and terror have been afflicting an increasing number of cities across the globe. This has encompassed cities engulfed by enduring wars and conflicts (Baghdad, Jenin, and Kabul) and cities situated outside immediate battle zones, but which have suffered terror attacks (Brussels, London, and Paris). Consequently, research has explored issues such as the urbanization of war, security and surveillance, aerial warfare, immigration and border regimes. This growing body of research has brought together and stimulated crossdisciplinary dialogue between various fields of knowledge, specifically, politics, militarism, and economics (Amoore, 2006; Coaffee, 2009; Graham, 2008; 2010).

Within the context of urban warfare, the pioneering work of Weizman (2007) has called upon the need to move from flat to vertical conceptualizations of space, especially in contested environments. The vertical dimensions of above and below ground in regions of conflict have introduced an innovative and exciting research agenda (Bridge, 2013; Elden, 2013; Graham and 
Hewitt, 2013). Vertical scoping regimes operate at three different dimensions through the deployment of surveillance, securitization devices, and (para) military actions. In the air, growing numbers of drones, air traffic and satellite surveillance are used to sense human activity. On the surface, the construction of walls, fortifications, security towers, and checkpoints profoundly impact daily life experiences. Underground vertical spaces used for transporting people and materials, mining and infrastructure, bunkers and archeological digs, are less visible, but nonetheless, of great importance. This multifaceted interplay between warfare, ethno-national conflict, planning, and architecture is explored through the idea of volumetric geographies, a body of knowledge suggesting that space should be analyzed through a three-dimensional perspective (Graham, 2016; Leshem, 2015; McFarlane, 2016).

Despite these new and exciting research trajectories in the study of verticality, much research has become path-dependent and unidimensional in character in that it has focused chiefly on specific settings (e.g. geopolitically sensitive cities and global cities) and types of structures (the tallest skyscrapers and architectural spectacles). Following the work of colleagues (Harker, 2014; Harris, 2015; Kaika, 2010), we advocate the use of a multidimensional prism to explore controversies over sovereignty, legitimacy, capital and identities, in a range of urban environments. If we are to engage in the exploration of urban verticality, it is essential to study a range of urban political environments, examine both exceptional edifices and more ordinary structures and sites, and acknowledge the plurality of theories and theoretical perspectives. 


\section{Rokem et-al (2017) Intervention in Urban Geopolitics, Political Geography Journal}

\section{Pre-publication version (Accepted $2^{\text {nd }}$ April 2017)}

Urban verticality has expressed itself in the form of towers, architectural wonders, and monumental structures for centuries. Beginning as imagined towers (Tower of Babel), celebrated structures of an epic scale (Pyramids), impressive places of worship (cathedrals), and finally, evertaller skyscrapers, vertical structures have come to dominate real and imagined urban skylines. At present, towers of unprecedented height are trademarks of global and globalizing cities. Supertall buildings are used as instruments for switching between different forms of capital and for increasing global urban competitiveness (Acuto, 2010; King, 2004). However, the recent rise of exceptional skyscrapers in the City of London and Manhattan, for example, does not necessarily reflect just the desire to secure and enhance the global economic position of cities. Rather, it epitomizes the conjunction of political, economic, and cultural agendas (Appert and Montes, 2015; Charney, 2014; Kaika, 2010), thus making “... tall buildings sites as a nexus of power made visible..." (McNeill, 2005: 53).

Notwithstanding their prominence, exceptional towers in global and divided cities are not necessarily the sole manifestation of urban verticality. Studying vertical dynamics in more ordinary and less politically or economically unique settings, and exploring verticality in exceptional places, albeit from diverse theoretical perspectives, can expose additional social and political rationales and trajectories in our understanding of vertical urbanism (Harker, 2014). Exploring urban verticality requires an understanding that socio-spatial relations are shaped by the interplay of global forces, national agendas, local divisions, and everyday life experiences (Rosen and Charney, 2016). These are neither separate nor isolated forces, but rather work together in varying constellations to shape space and society. For example, high-rise development in Ramallah and in 
the new city of Rawabi does not merely reflect the geopolitical conditions constraining Palestinian horizontal expansion (suburbanization) and dictating upward development. Rather, it results from the interplay between these restrictive conditions and the greater acceptance of residential towers in Palestinian society. In Jerusalem - an archetypical divided and contested city (Shlay and Rosen, 2015) - different manifestations of height, e.g., unauthorized ordinary high-rises, the Separation Wall, and impressive towers illustrate the intertwining geopolitics of verticality (Charney and Rosen, 2014). A crucial element in the analysis of verticality is thus the need to move beyond a unidimensional perspective and explore the plurality of conditions that underpin verticality. Developing a more complex understanding of urban arenas involves meshing various theoretical streams and abandoning "the hopeless efforts to apply quasi-scientific rigour to case selection based on attempting to control for difference across cities" (Robinson, 2016: 194). Despite the variance in urban environments, local contexts, and experiences, the study of urban verticality should facilitate analyses that cut across differences. Analysis should not be limited to a specific category of cities, e.g., global or divided cities, nor should it be conducted through the narrow prism of a single field of knowledge. It should apply to a gamut of urban settings and bridge across various disciplines, e.g., geography, urban studies, architecture and planning (Harris, 2015).

Graham and Hewitt (2013), expand critical debates on vertical urbanism by linking between highrise construction and the social secession of elites. Moving upwards and employing a range of security arrangements parallels gentrification and the construction of enclaves for the wealthy (Pow, 2011). The growing popularity of inner-city living and the global diffusion of high-end condominiums emphasize the increased tendency of elites to escape the street level and occupy 
top floors of luxury towers. Vertical secession, via practically living in the skies, challenges the dominant perception that segregation is expressed solely horizontally in enclosed and gated enclaves (Graham, 2015; 2016; Rosen and Walks, 2013). Research on urban verticality in cities of the Global South provides yet another vantage point from which to understand urban geopolitics under conditions of informality. For eight years, Torre de David in Caracas - an incomplete office tower had functioned as a slumscraper (or the world's tallest vertical organized favela), an informal vertical community of squatters that lacks basic infrastructure such as working elevators, electricity, and running water. Examining the daily life experience in such an environment draws attention to another set of issues including social injustice, homelessness, activism and socio-economic disparities. Hence, looking at a variety of urban settings enables the study of urban verticality through the lens of the lived experiences of people (Harker, 2014; Robinson, 2006).

We would like to conclude with two final thoughts on the connection between geopolitics and urban verticality. First, following Cowen and Smith (2009), it is possible to think of urban verticality as being situated somewhere on the spectrum between geopolitics and geoeconomics. In the past, imposing urban verticality was an instrument among rival private corporations and interest groups that sought greater market share through public exposure in urban skylines (Domosh, 1988; Fenske and Holdsworth, 1992). More recently, as cities have become global showcases, emerging economies use the vertical dimension to pursue a more significant role in global affairs. In a grandiose display of a well-orchestrated state showoff, countries such as Azerbaijan, Saudi Arabia, United Arab Emirates, and Qatar have been constructing ever-taller and ever-impressive skyscrapers as part of a strategy to strengthen their claim for an influential position in the global 
economy. A second point concerns the relationship between urban verticality and iconicity. The construction of high-rise towers in Jerusalem, for example, highlights the interactions between urban icons and ordinary tall buildings and exposes how the multiplicity of socio-spatial processes (such as globalization, geopolitics and day-to-day experiences) work together to reshape verticality. Unpacking local conditions, being more sensitive to the interplay between forces, and accepting the plurality of theories and theoretical perspectives including divided cities, militarization of space, and colonialism provides an opportunity for a more comprehensive exploration of geopolitics and political geographies through the lens of urban verticality. 
The urban and the geopolitical as categories of theory and practice: front-line reflections

\author{
Dr. Till F. Paasche (Soran University, Kurdistan Region, Iraq and Prof. James D. Sidaway, National \\ University of Singapore.
}

"I'll begin with the following hypothesis: Society has been completely urbanized. This hypothesis implies a definition: An urban society is a society that results from a process of complete urbanization. This urbanization is virtual today, but will become real in the future." Henri Lefebvre $(2003,1)$ [original 1970]

We want to "scale-up" - building on prior writing on urban geopolitics - the theoretical effort of connecting geopolitics and the urban. However, in asking what happens when two much debated terms - urban and geopolitical - are combined, we draw on praxis and this means scaling back down - to city streets, buildings and barricades. For Till, this has been as a participant observer as a frontline medic with revolutionary secular Kurdish-led forces in Syria's civil war and then as member of an NGO team of medically trained veterans providing combat casualty currently working in Mosul (http://mermt.com/) following doctoral research on geographies of private security in neoliberalizing Cape Town (Paasche et al. 2014). For James, the reflections relate to fieldwork since 2009 with Till in Cambodia, Iraqi Kurdistan and Mozambique plus our earlier joint experiences in the English naval port-city of Plymouth, to where we return in our closing words here. 
More than two decades ago, Gearóid Ó Tuathail (1996: 66) wrote about the: "heterogeneous histories of "geopolitics" as a twentieth-century concept that functions as a gathering point for the production of geographical meaning about "international politics." In other words, geopolitics is what linguistics and semioticians call a polysemic sign; it means many things. Critical readings of geopolitics abound - along with conservative and right-wing ones. Its meaning is contested and many pages in Political Geography (and allied journals) have been dedicated to exploring these contests and enriching critical readings of geopolitics.

What of the urban side of the equation? Questions about the relationship of the country and the city are not new. In recent years however, there has been a reanimated debate about the epistemological and ontological status of the urban. This has led to a fresh wave of questioning what is the urban, how we recognize it and how should it be studied? It was once held that China's revolution meant surrounding the cities from the countryside. This aphorism attributed to Mao, found expression in other peasant revolutions, notoriously the Khmer Rouge, but from Mozambique to Cuba, Third World socialisms of the 1960 s and 1970 s arguably embodied something of Mao's geopolitical vision, in respect of urban questions (Forbes and Thrift, 1987). But in the years since, when the socialist Third World was overwritten by neoliberalism and other capitalist restorations associated with the crisis and eclipse of 1960 s-style state socialism, Henri Lefebvre's The Urban Revolution has inspired claims that today there is nowhere outside the urban (Brenner and Schmid, 2015). In other words, urban hinterlands encompass the world. This is a startling claim - a notion of planetary urbanism that can usefully be re-read through a century of 
debate about the status of the peasantry in underdeveloped lands and the nature of combined and uneven development. Moreover it invites a shift in thinking about cities not simply as category of analysis, but "as a category of practice: a representation of urbanization processes that exceed it." (Wachsmuth, 2014: 76). This invites reconsideration of how the idea of cities operates on our cognitive maps of the world (Angelo, 2017).

Moreover, the correlation of the rise of conceptions of planetary urbanism with debates about globalization and the Anthropocene in recent decades has structural parallels with an earlier moment where representations of space and time shifted. At the dawn of the twentieth century, Mackinder's geopolitics articulated a vision of spatial closure, when global strategy arose in the context of there being no more empty spaces on the map to colonize (Kearns, 1984). Hence:

"From the present time forth...we shall again have to deal with a closed political system, and none the less that it will be of worldwide scope. Every explosion of social forces, instead of being dissipated in a surrounding circuit of unknown spaces and barbaric chaos, will be sharply re-echoed from the far side of the globe, and weak elements in the political and economic organism of the world will be shattered in consequence. There is a vast difference of effect in the fall of a shell into an earthwork and its fall amidst the closed spaces and rigid structures of a great building or a ship." (Mackinder, 1904: 422).

Since then, both geopolitics and the urban are more tightly bound and nature is folded into the relationship between them. Here is productive to historicize. Reading Neil Smith's (1984) rich account of the urbanization of capital, uneven development and the production of a second nature and Derek Gregory's (2016) visceral one on the natures of war reframe Mackinder's abstract geopolitics. So, the First World War saw warfare mechanized, cities increasingly became targets by the Second World War and the Cold War made them all strategic sites. With the advent of the 
Rokem et-al (2017) Intervention in Urban Geopolitics, Political Geography Journal Pre-publication version (Accepted $2^{\text {nd }}$ April 2017)

global war on terror there is no hiding place - nowhere wholly outside surveillance and securitization.

"Each building becomes a fortress, each street a sniper's alley. Isis use human shields. Cities are very difficult to get back." YPG volunteer, quoted in Blake (2016).

Whilst what we have said above may appear rather abstract and theoretical, in the rest of this intervention we want to add a more practical perspective to our discussion. Over the last decade we have (sometimes with others) been researching security and space in three postcolonial cities: Maputo (Paasche and Sidaway, 2010), Phnom Penh (Sidaway et al, 2014) and Erbil (the capital of the Kurdistan autonomous region in Iraq). The last of these studies took us "outside" the city, to frontlines ISIS/ISIL (hereafter, as called by all of our informants and comrades, Daesh) at Kirkuk as well as to insurgent areas of the bases of the Kurdistan Workers Party (PKK) at Qandil near to the Iran-Iraq-Turkey border (Paasche and Sidaway, 2015). Building on links established there, Till then joined the People's Protection Units (YPG) in the Federation of Northern Syria - Rojava, and in two 6 month deployments served as a frontline medic in six major combat operations against Daesh. Till's experiences inform the rest of this intervention. Looking at the war the Kurds and their allies are waging against Daesh starkly illustrates these overlaps of the urban and geopolitics that we approached in more theoretical terms above.

Daesh is commonly referred to as ruling a territory as big as Great Britain (Johnston, 2014). Here the idea of territory can be misleading. Besides their cities, Daesh's territory consists of scarcely populated deserts. Instead of using the idea of territory, the IS might better be described as a 
Rokem et-al (2017) Intervention in Urban Geopolitics, Political Geography Journal Pre-publication version (Accepted $2^{\text {nd }}$ April 2017)

network of cities connected by roads and a series of checkpoints. Now, one might argue that Daesh is also about oil fields, access to international boundaries, critical infrastructure, states, refugees, apocalypse and ideology, as dissected in accounts like Clark (2014) and Moubayed (2015). Indeed, this is true, but it is the cities from where the control over strategic spaces and places is exercised.

Consider the strategy of the YPG, currently the most effective force fighting Daesh. When in spring 2015 the international coalition finally decided to support the YPG with close air support, the tables in north-east Syria turned. Instead of defending their lands, the YPG was finally in a position to go on the offensive and to (re-)take spaces from Daesh. While the very first operation with air support merely pushed the enemy into the Syrian desert to give YPG space to breath and to plan their next strategic moves, all operations that followed targeted particular cities. Once the cities fell, the wider tactical or geopolitical objectives such as control over oil fields or supply lines could easily be achieved. To give some examples of cities that were taken in 2015-16:

- Tel Abiat to cut Daesh's supply lines to Turkey and to connect the two separate Kurdish areas of control Cizire and Kobane.

- Hasake to control the gateway to the Der Ezor oil fields and routs that link Racca and Mosul, as well as to secure the south-eastern flank of the canton Jezire.

- Tishreen to secure a vital water dam and access to strategic bridge over the Euphrates.

- Al Shadadi to cut the connection between the two IS capitals Racca and Mosul and to gain control over oil fields south of the city.

- Manbij to cut Daesh's remaining supply lines to Turkey and to start connecting Afrin and Kobane canton. 
In fact, Daesh does not stand a chance on open ground against airstrikes and thus invariably withdraws to the cities where they form their defences hiding amongst civilians (what they leave behind though are suicide bombers and a landscape of mines and booby traps). Thus, when commentators are debating the loss of territory, it is in fact the gain or loss of strategic cities primarily. With these come the surrounding desert including strategic infrastructure (or 'logistic') sites and lines that connect with the cities. Much of the current geopolitical turmoil in Syria and Iraq is about this interface, in short cities and their relationships to territory. All forces that fight successfully in the region understood that. Anyone else ended up with little strategic relevance.

So, the city in geopolitics is a contested space, practically and figuratively. Explaining the YPG's Manbij operation merely by outlining its wider objectives, the connection of the cantons and cutting off Daesh from Turkey and so on provides only a detached understanding of the unfolding events. When news outlets state something along the lines of 'Deash is losing ground in northern Syria and around Mosul,' they give us a synopsis of the war. However, understanding means learning how this connects with what went on in cities and why. Cities are at the interface of scales through which we can understand this war in its details. The campaign around Manbij embodies the tense relationship the YPG has with Turkey, the difficulties of the coalition support for the Kurds, while appeasing their NATO partner, the need and state of the new Kurdish-Arab alliances and the tunnels, trenches, barricades and tactics Daesh uses to defend their crumbling state. But looking at Manbij and Mosul since, is not only about black and yellow lines on large scale maps, but blood, tears and death lurking at every corner, behind every window. Yes, the concepts of city and 
geopolitics are contested and so they should be. They belong together as categories of theory and praxis, illuminated by the horrors of war. Whilst these may be encountered daily in Mosul, readers of this and the preceding interventions will find ample occasion to (in words that the other of us wrote of the English port city of Plymouth in the light of past and present manifestations of security and insecurity there): "negotiate how the repercussions of militarism, war, and death are folded into the textures of an everyday urban fabric." (Sidaway 2009: 1091). 
Rokem et-al (2017) Intervention in Urban Geopolitics, Political Geography Journal Pre-publication version (Accepted $2^{\text {nd }}$ April 2017)

\section{Funding}

The corresponding author Dr. Jonathan Rokem's time preparing this paper was funded by the European Union's Horizon 2020 research and innovation programme under the Marie Sklodowska-Curie grant agreement No 658742 and is part of the outputs from the Contested Urbanism Project, for further information visit: https://www.ucl.ac.uk/bartlett/architecture/research/space-syntax/contested-urbanism

\section{References}

Abujidi, N. (2014). Urbicide in Palestine: spaces of oppression and resilience. London: Routledge.

Acuto, M. (2010). High-rise Dubai urban entrepreneurialism and the technology of symbolic power. Cities, 27(4), 272-284.

Agamben, G. (2015). Stasis. La guerra civile come paradigma politico, Homo sacer, II, 2. Torino: Bollati Boringhieri.

Agier, M. (2012). From refuge the ghetto is born: Contemporary figures of heterotopias. In R. Hutchinson \& Bruce D Haynes (Eds.), The Ghetto: Contemporary Global Issues and Controversies (pp. 265-292). Boulder, CO: Westview Press.

Agnew, J. (2003). Geopolitics: Re-visioning World Politics, 2nd ed. Routledge.

Allegra, M. Casaglia, A. \& Rokem, J. (2012). The Political Geographies of Urban Polarization: A Critical Review of Research on Divided Cities: Political geographies of urban polarization. Geography Compass, 6(9), 560-574.

Allegra, M. Bono, I. Rokem, J. with Casaglia, A. Marzorati, R. and Yacobi, H. (2013). Critical Commentary: Rethinking cities and protests in Middle East and North Africa. Urban Studies. 50(9): 1675-1688.

Amin, A. and Thrift, N. J. (2002) Cities: Reimagining the Urban. Cambridge: Polity Press.

Amoore, L. (2006). Biometric borders: governing mobilities in the war on Terror. Political Geography 25(3), 336-351.

Anderson, J. (2010). Democracy, Territoriality and Ethno- National Conflict: A Framework for Studying Ethno- Nationally Divided Cities. Paper n.18, Retrieved from www.conflictincities.org.

Angelo, H. (2017). From the city lens toward urbanisation as a way of seeing: Country/city binaries on an urbanising planet 
Rokem et-al (2017) Intervention in Urban Geopolitics, Political Geography Journal Pre-publication version (Accepted $2^{\text {nd }}$ April 2017)

Appert, M. \& Montes, C. (2015). Skyscrapers and the redrawing of the London skyline: a case of territorialisation through landscape control. Articulo - Journal of Urban Research Special, Issue 7, http://articulo.revues.org/2784.

Bamat, J. (2016, June 27). Paris, London mayors pledge to work "closer than ever" despite Brexit. Retrieved from http://www.france24.com/en/20160627-brexit-london-pariswork-closer-hidalgo-khan

Baumann, H. (2015). Enclaves, borders, and everyday movements: Palestinian marginal mobility in East Jerusalem. Cities, 59, 173-182.

BBC News (2016 August $3^{\text {rd }}$ ). More armed police set to protect London: (http://www.bbc.co.uk/news/uk-36961338) [Accessed March 2017]

Belloni, M. (2016). Learning How to Squat: Cooperation and Conflict between Refugees and Natives in Rome. Journal of Refugee Studies, 29 (4), 506-527.

Blake, M. (2016). It wasn't about killing people': what drove a British farmer to the Syrian frontline? The Guardian 29 October https://www.theguardian.com/world/2016/oct/29/isis-wasnt-about-killing-peoplewhat-drove-british-farmer-syrian-frontline.

Bollens, S. (2012). City and Soul in Divided Societies. London and New York: Routledge.

Brand, R. \& Fregonese, S. (2013). The radicals' city: urban environment, polarisation, cohesion. Farnham, Surrey: Ashgate.

Brenner, N. \& Schmid, C. (2015). Towards a new epistemology of the urban?, City, 19(2-3), 151-182.

Brickell, K. (2012). "Mapping" and "doing" critical geographies of home. Progress in Human Geography, 36(2).

Brickell, K. (2012). Geopolitics of Home. Geography Compass, 6(10), 575-588.

Bridge, G. (2013). Territory, now in 3D! Political Geography, 34, 55-57.

Caldeira, T. (2000). City of Walls: Crime, Segregation, and Citizenship in Sao Paulo. Berkeley: University of California Press.

Castillo, G. (2010). Cold War on the home front: the soft power of midcentury design. Minneapolis: University of Minnesota Press.

Charney, I. (2014). Transforming a tower: how did the One World Trade Center eclipse the Freedom Tower? Area, 46(3), 249-255.

Charney, I. \& Rosen, G. (2014). Splintering skylines in a fractured city: high-rise geographies in Jerusalem. Environment and Planning D: Society and Space, 32(6), 1088-1101.

Clark, P. (2014). The roots of the Syrian crisis. Critical Muslim 11, 1-20.

Clark, L. (2016). Blitzkrieg: myth, reality and Hitler's lightening war-France, 1940. London: Atlantic Books.

Coaffee, J. (2004). Rings of Steel, Rings of Concrete and Rings of Confidence: Designing out Terrorism in Central London pre and post September 11th. International Journal of Urban and Regional Research, 28(1), 201-211. 
Rokem et-al (2017) Intervention in Urban Geopolitics, Political Geography Journal Pre-publication version (Accepted $2^{\text {nd }}$ April 2017)

Coaffee, J. (2009). Terrorism, Risk and the Global City: Towards Urban Resilience. London and New York: Routledge.

Colomina, B. (2007). Domesticity at war. Cambridge, Mass: MIT Press.

Coward, M. (2002). Community as Heterogeneous Ensemble: Mostar and Multiculturalism. Alternatives, 27(1), 29-66.

Coward, M. (2007). "Urbicide" Reconsidered. Theory and Event, 10(2).

Coward, M. (2009). Urbicide. The politics of urban destruction. Oxon: Routledge.

Cowen, D. \& Smith N. (2009). After geopolitics? From the geopolitical social to geoeconomics, Antipode, 41(1), 22-48.

Dalby, S. (2010). Recontextualising violence, power and nature: The next twenty years of critical geopolitics? Political Geography, 29(5), 280-288.

Daniel, R. M. (2015). Herman Miller's Action Office: Corporate Interiors in the Cold War. Interiors: Design, Architecture and Culture, 6(1), 5-20.

Darling, J. (2010). A city of sanctuary: the relational re-imagining of Sheffield's asylum politics. Transactions of the Institute of British Geographers, 35(1), 125-140.

Darling, J. (2016). Privatising asylum: neoliberalisation, depoliticisation and the governance of forced migration. Transactions of the Institute of British Geographers, 41(3), 230243.

Davie, M. (1983). Comment fait-on la guerre a Beyrouth? Herodote, (29-30), 41.

Demarest, G. (1995). Geopolitics and Urban armed conflict in Latin America. Small Wars \& Insurgencies, 6(1), 44-67.

Domosh, M. (1988). The symbolism of the skyscraper: case studies of New York's first tall building, Journal of Urban History, 14(3), 321-345.

Donia, R. (2005). Sarajevo. A biography. London: Hurst.

Dowler, L. (1998). “And They Think I"m Just a Nice Old Lady' Women and War in Belfast, Northern Ireland. Gender, Place \& Culture, 5(2), 159-176.

Dowler, L. (2001). Preserving The Peace and Maintaining Order: Deconstructing The Legal Landscape of Public Housing in West Belfast, Urban Geography, 22(2), 100-105.

Elden, S. (2013). Secure the volume: Vertical geopolitics and the depth of power. Political Geography, 34, 35-51.

Fawaz, M. (2016). Planning and the refugee crisis: Informality as a framework of analysis and reflection. Planning Theory.

Fawaz, M. Harb, M. \& Gharbieh, A. (2012). Living Beirut's Security Zones: An Investigation of the Modalities and Practice of Urban Security: Living Beirut's Security Zones. City \& Society, 24(2), 173-195.

Forbes, D. \& Thrift, N. (1987). Introduction in Forbes, D. \& Thrift, N. (Eds.) The Socialist Third World: Urban Development and Territorial Planning. Oxford and New York: Basil Blackwell, 1-26. 
Rokem et-al (2017) Intervention in Urban Geopolitics, Political Geography Journal Pre-publication version (Accepted $2^{\text {nd }}$ April 2017)

Fregonese, S. (2009). The urbicide of Beirut? Geopolitics and the built environment in the Lebanese civil war (1975-1976). Political Geography, 28(5), 309-318.

Fregonese, S. (2012). Urban Geopolitics 8 Years on. Hybrid Sovereignties, the Everyday, and Geographies of Peace. Geography Compass, 6(5), 290-303.

Fregonese, S. \& Ramadan, A. (2015). Hotel Geopolitics: A Research Agenda. Geopolitics, 20(4), 793-813.

Ginn, F. (2012). Dig for Victory! New histories of wartime gardening in Britain. Journal of Historical Geography, 38(3), 294-305.

Graham, S. (2009). Disruption by design: urban infrastructure and political violence. In S. Graham (Ed.), Disrupted cities. When infrastructure fails (pp. 111-129). London: Routledge.

Graham, S. (2010). Cities Under Siege: the new military urbanism. London, New York: Verso. Graham, S. (2015). Luxified skies: how vertical urban housing became an elite preserve. City, 19(5), 618-645.

Graham, S. (2016). Vertical: The City from Satellites to Bunkers. New York: Verso Books.

Graham, S. (eds.) (2004a). Cities, war, and terrorism: towards an urban geopolitics. Malden, MA: Blackwell Publishing.

Graham, S. (2004b). Constructing Urbicide by Bulldozer in the Occupied Territories. In S. Graham (Ed.), Cities, war and terrorism: towards an urban geopolitics (pp. 192-213). Oxford: Blackwell.

Graham, S. \& Hewitt, L. (2013). Getting off the ground: On the politics of urban verticality. Progress in Human Geography, 37(1), 72-92.

Graham, S., \& Wood, D. (2003). Digitizing Surveillance: Categorization, Space, Inequality. Critical Social Policy, 23(2), 227-248.

Gregory, D. (2011). Lines of descent. Open Democracy (https://www.opendemocracy.net/derek-gregory/lines-of-descent) (Accessed September 2016).

Gregory, D. (2016). The Natures of War, Antipode, 48, 3-56.

Gwynn, R. (1983). The number of Huguenot immigrants in England in the late seventeenth century. Journal of Historical Geography, 9(4), 384-395.

Harker, C. (2009). Spacing Palestine through the home. Transactions of the Institute of British Geographers, 34(3), 320-332.

Harker, C. (2011). Geopolitics and family in Palestine. Geoforum, 42(3), 306-315.

Harker, C. (2014). The only way is up? Ordinary topologies of Ramallah. International Journal of Urban and Regional Research, 38(1), 318-335.

Harris, A. (2015). Vertical urbanisms: opening up geographies of the three-dimensional city. Progress in Human Geography 39 (5), 601-620.

Hepburn, A.C. (2004). Contested Cities in the Modern West. New York: Palgrave. 
Rokem et-al (2017) Intervention in Urban Geopolitics, Political Geography Journal Pre-publication version (Accepted $2^{\text {nd }}$ April 2017)

Hewitt, L. \& Graham, S. (2015). Vertical cities: Representations of urban verticality in 20thcentury science fiction literature. Urban Studies, 52(5), 923-937.

Hirst, P. Q. (2005). Space and power: politics, war and architecture. Cambridge; Malden, MA: Polity.

Holston, J. (2008) Insurgent Citizenship: Disjunctions of Democracy and Modernity in Brazil, NJ: Princeton University Press.

Hyndman, J. (2001). Towards a feminist geopolitics. The Canadian Geographer/Le Géographe Canadien, 45(2), 210-222.

Hyndman, J. (2004). Mind the gap: bridging feminist and political geography through geopolitics. Political Geography, 23(3), 307-322.

Johnston, I. (2014). The rise of Isis: Terror group now controls an area the size of Britain, expert claims. The Independent 3.9

http://www.independent.co.uk/news/world/middle-east/the-rise-of-isis-terror-groupnow-controls-an-area-the-size-of-britain-expert-claims-9710198.html.

Kaika, M. (2010). Architecture and crisis: re-inventing the icon, re-imag(in)ing London and re-branding the City. Transactions of the Institute of British Geographers, 35(4), 453474.

Kearns, G. (1984). Closed Space and Political Practice: Frederick Jackson Turner and Halford Mackinder, Environment and Planning, D 2(1), 23-34.

Kershen, A. J. (2005). Strangers, aliens and Asians: Huguenots, Jews and Bangladeshis in Spitalfields, 1660-2000. London ; New York: Routledge.

King, A. (2004). Spaces of Global Cultures: Architecture, Urbanism, Identity. London and New York: Routledge.

Kwan, M. \& Schwanen, T. (2016). Geographies of Mobility, Annals of the American Association of Geographers, 106(2), 243-256.

Lambert, D. (1965). The sheltered days: Growing up in the war. Deutsch.

Lees, L. (2012). The geography of gentrification Thinking through comparative urbanism. Progress in Human Geography, 36(2), 155-171.

Lefebvre, H. (2003). The Urban Revolution. Minneapolis MN: University of Minnesota Press.

Leitner, H. Sheppard, E. \& Sziarto, K. M. (2008). The spatialities of contentious politics.

Transactions of the Institute of British Geographers, 33 (2), 157-172.

Leshem, N. (2015). "Over our dead bodies": Placing necropolitical activism. Political Geography, 45, 34-44.

Lloyd, C. Shuttleworth, I. Won, D, (2014). Social-spatial segregation, London: Policy Press.

Loraux, N. (2006). La città divisa: I'oblio nella memoria di Atene. Vicenza: Neri Pozza.

Mackinder, H. J. (1904). The Geographical Pivot of History, The Geographical Journal, 23(4), 421-437.

Malkki, L. (1992). National Geographic: The Rooting of Peoples and the Territorialization of National Identity Among Scholars and Refugees. Cultural Anthropology, 7(1), 24-44. 
Rokem et-al (2017) Intervention in Urban Geopolitics, Political Geography Journal Pre-publication version (Accepted $2^{\text {nd }}$ April 2017)

Marcuse, P. (1997). The Enclave, the Citadel, and the Ghetto: What has changed in the PostFordist U.S. City. Urban Affairs Review, 33, 228-264.

Marcuse, P. (2006). Enclaves Yes Ghettos No: Segregation and the State. In Varady, D. (eds.) Desgregating the City, Ghettos, Enclaves and Inequality, Albany: State University of New York Press, pp. 15-30.

Marcuse, P. van Kempen, R. (eds.) (2002). Of states and cities: the partitioning of urban space. Oxford University Press, Oxford; New York.

Martin, D. (2015). From spaces of exception to "campscapes": Palestinian refugee camps and informal settlements in Beirut. Political Geography, 44, 9-18.

Massey, D. (1994). Space, Place and Gender. Minneapolis: University of Minnesota Press.

McFarlane, C. (2016). The geographies of urban density topology, politics and the city. Progress in Human Geography, 40, 629-648.

McNeill, D. (2005). Skyscraper geography. Progress in Human Geography, 29(1), 41-55.

Morrison, K. (2016). Sarajevos holiday inn on the frontline of politics and war. London: Palgrave Macmillan.

Moubayed, S. (2015) Under the Black Flag: at the frontier of the new jihad. London and New York: I B Tauris.

Moulin, C. \& Nyers, P. (2007). "We Live in a Country of UNHCR"-Refugee Protests and Global Political Society. International Political Sociology, 1(4), 356-372.

Musterd, S. Ostendorf, W. (2013). Urban Segregation and the Welfare State: Inequality and Exclusion in Western Cities. London: Routledge.

Nagel, C. (2002). Reconstructing space, re-creating memory: sectarian politics and urban development in post-war Beirut. Political Geography, 21(5), 717-725.

Navaro-Yashin, Y. (2012). The make-believe space. Affective geography in a postwar policy. Durham and London: Duke University Press.

Nightingale, C. H. (2012). Segregation: A Global History of Divided Cities. Chicago: The University of Chicago Press.

Nowicki, M. (2014). Rethinking Domicide: Towards an Expanded Critical Geography of Home: Rethinking Domicide. Geography Compass, 8(11), 785-795.

Nsouli, B. (2001). La sagesse de Job. In J. Tabet (Ed.), Beyrouth: la brulure des reves. Paris: Autrement.

Ó Tuathail, G. (1996). Critical Geopolitics: the politics of writing global space. London: Routledge.

Oldfield, S., Parnell, S. (2014). Handbook on Cities in the Global South. London: Routledge.

Paasche T. F., Yarwood R. \& Sidaway J. D. (2014) Territorial tactics: the socio-spatial significance of private policing tactics in Cape Town, Urban Studies 51 (8), 1559-1575.

Paasche, T. F. \& Sidaway, J. D. (2010). Transecting security and space in Maputo. Environment and Planning A, 42(7), 1555-1576. 
Rokem et-al (2017) Intervention in Urban Geopolitics, Political Geography Journal Pre-publication version (Accepted $2^{\text {nd }}$ April 2017)

Paasche, T. F. \& Sidaway, J. D. (2015). Transecting security and space in Kurdistan, Iraq, Environment and Planning A, 47(10), 2113-2133.

Pain, R. (2015). Intimate war. Political Geography, 44, 64-73.

Pain, R. \& Smith, S. (2008). Fear: critical geopolitics and everyday life. Aldershot, Hants, England ; Burlington, VT: Ashgate.

Pain, R. Panelli, R., Kindon, S., \& Little, J. (2010). Moments in everyday/distant geopolitics: Young people's fears and hopes. Geoforum, 41(6), 972-982.

Papadakis, Y. (2005). Echoes from the dead zone: across the Cyprus divide. London; New York : New York: I.B. Tauris; Distributed in the U.S.A. by Palgrave Macmillan.

Park, R. Burgess, E. \& McKenzie, R. (1925). The City. Chicago: University of Chicago Press.

Pascucci, E. (2016). Transnational disruptions: materialities and temporalities of transnational citizenship among Somali refugees in Cairo. Global Networks, 16(3), 326343.

Pascucci, E. (Forthcoming). Community Infrastructures: Shelter, Self-Reliance and Polymorphic Borders in Urban Refugee Governance. Territory, Politics and Governance.

Peach, C. (2009). 'Slippery Segregation: Discovering or Manufacturing Ghettos'?, Journal of Ethnic and Migration Studies, Vol. 35(9), 1381-1395.

Peck, J. (2015). Cities beyond Compare? Regional Studies, Vol. 49(1), 183-186.

Porteous, J. D., \& Smith, S. E. (2001). Domicide: the global destruction of home. Montréal ; Ithaca: McGill-Queen's University Press.

Pow, C. P. (2011). Living it up: Super-rich enclave and transnational elite urbanism in Singapore. Geoforum, 42(3), 382-393.

Pullan, W. (2006). Locating the Civic in the Frontier: Damascus Gate. In M. Miessen \& S. Basar (Eds.), Did someone say participate?: An atlas of spatial practice. Cambridge, Mass. MIT Press.

Pullan, W. (2011). Frontier urbanism: the periphery at the centre of contested cities. The Journal of Architecture, 16(1), 15-35. https://doi.org/10.1080/13602365.2011.546999

Pullan, W. Misselwitz, P., Nasrallah, R. \& Yacobi, H. (2007). Jerusalem's Road 1. City, 11(2), 176-198.

Ramadan, A. (2008). The Guests' Guests: Palestinian Refugees, Lebanese Civilians, and the War of 2006. Antipode, 40(4), 658-677.

Ramadan, A. (2009). Destroying Nahr el-Bared: Sovereignty and urbicide in the space of exception. Political Geography, 28(3), 153-163.

Ramadan, A. (2010). In the Ruins of Nahr al-Barid: Understanding the Meaning of the Camp. Journal of Palestine Studies, 40(1), 49-62.

Ramadan, A. (2013). Spatialising the refugee camp. Transactions of the Institute of British Geographers, 38(1), 65-77.

Ridgley, J. (2008). Cities of Refuge: Immigration Enforcement, Police, and the Insurgent Genealogies of Citizenship in U.S. Sanctuary Cities. Urban Geography, 29(1), 53-77. 
Rokem et-al (2017) Intervention in Urban Geopolitics, Political Geography Journal Pre-publication version (Accepted $2^{\text {nd }}$ April 2017)

Robinson, J, (2006). Ordinary Cities: Between Modernity and Development. London and New York: Routledge.

Robinson, J. (2016). Comparative urbanism: new geographies and cultures of theorizing the urban. International Journal of Urban and Regional Research, 40(1), 187-199.

Rokem, J. (2016a). Introduction: Learning from Jerusalem - Rethinking Urban Conflicts in the $21^{\text {st }}$ Century. CITY, Vol. 20(3): 472-482.

Rokem, J. (2016b). Beyond Incommensurability: Jerusalem and Stockholm from an Ordinary Cities Perspective. CITY, 20 (3): 451-461.

Rokem, J. Allegra, M. (2016). Planning in Turbulent Times: Exploring Planners Agency in Jerusalem. International Journal of Urban and Regional Research, 40(3), 640-657.

Rokem, J. and Boano, C. Eds. (In press) Urban Geopolitics: Rethinking Planning in Contested Cities, London, Routledge.

Rokem, J. and Vaughan, L. (2017). Segregation, Mobility and Encounters in Jerusalem: The Role of Public Transport Infrastructure in Connecting the 'Divided City', Urban Studies, DOI: $10.1177 / 0042098017691465$

Rose, M. (2016). Feminist Theory and the European Refugee Crisis. Conspectus Borealis, $1(1)$.

Rosen, G. \& Walks, A. (2013). Rising cities: Condominium development and the private transformation of the metropolis. Geoforum, 49, 160-172.

Rosen, G. and Chareny, Y. (2016). Divided we rise: politics, architecture and vertical cityscapes at opposite ends of Jerusalem, Transactions of the Institute of British Geographers, 41.2: 163-174.

Roy, A. (2016). Who's Afraid of Postcolonial Theory. International Journal of Urban and Regional Research, Vol 40(1), 200-209.

Sandercock, L. (2003). Mongrel Cities of the 21st Century. New York: Continuum Press.

Sanyal, R. (2012). Refugees and the City: An Urban Discussion: Refugees and the City. Geography Compass, 6(11), 633-644.

Sanyal, R. (2014). Urbanizing Refuge: Interrogating Spaces of Displacement: Urbanizing refugee spaces. International Journal of Urban and Regional Research, 38(2), 558-572.

Shlay, A. B., \& Rosen, G. (2015). Jerusalem: The Spatial Politics of a Divided Metropolis. Cambridge: Polity Press.

Sidaway, J. D. (2009). Shadows on the Path: Negotiating Geopolitics on an Urban Section of Britain's South West Coast Path, Environment and Planning D 27 (6): 1091-1116.

Sidaway, J. D., Paasche, T. F., Woon, C. Y. \& Keo, P. (2014). Transecting security and space in Phnom Penh, Environment and Planning A, 46(5), 1181-1202.

Smets, P. Salman, T. (2008). Countering Urban Segregation: Theoretical and Policy Innovations from around the globe. Urban Studies, Vol. 45 (7), 1307-1332.

Smith, N. (1984). Uneven development: nature, capital and the production of space. Oxford: Basil Blackwell. 
Rokem et-al (2017) Intervention in Urban Geopolitics, Political Geography Journal Pre-publication version (Accepted $2^{\text {nd }}$ April 2017)

Smith, N. (2002). New globalism, new urbanism: gentrification as global urban strategy. Antipode, 34(3), 427-450.

Smith, S. (2012). Intimate Geopolitics: Religion, Marriage, and Reproductive Bodies in Leh, Ladakh. Annals of the Association of American Geographers, 102(6), 1511-1528.

Squire, V. (2016, August 16). Welcome to City Plaza, Athens: a new approach to housing refugees. The Conversation. Retrieved from https://theconversation.com/welcome-tocity-plaza-athens-a-new-approach-to-housing-refugees-63904.

Tyner, J. A., Henkin, S., Sirik, S., \& Kimsroy, S. (2014). Phnom Penh during the Cambodian genocide: a case of selective urbicide. Environment and Planning A, 46(8), 1873-1891.

Varsanyi, M. W. (2008). Immigration Policing Through the Backdoor: City Ordinances, the "right to the City," and the Exclusion of Undocumented Day Laborers. Urban Geography, 29(1), 29-52.

Vasudevan, A. (2015). The makeshift city: Towards a global geography of squatting. Progress in Human Geography, 39(3), 338-359.

Vaughan, L., Arbaci, S. (2011). The Challenges of Understanding Urban Segregation. Built Environment, Vol. 37(2), 128-138.

Wachsmuth D. (2014). City as ideology: reconciling the explosion of the city form with the tenacity of the city concept. Environment and Planning D: Society and Space 31, 75-90.

Wacquant , L. (2016). Revisiting territories of relegation: Class, ethnicity and state in the making of advanced marginality, Urban Studies, 53(6): 1077-1088.

Wacquant, L. (2008). Urban Outcasts - A Comparative Sociology of Advanced Marginality. Cambridge: Polity Press.

Walker, K. E., \& Leitner, H. (2011). The Variegated Landscape of Local Immigration Policies in the United States. Urban Geography, 32(2), 156-178.

Weizman, E. (2007). Hollow Land, London: Verso.

Williams, A. M., \& Hall, C. M. (2000). Tourism and migration: New relationships between production and consumption. Tourism Geographies, 2(1), 5-27.

Wirth, L. (1938). Urbanism as a Way of Life. American Journal of Sociology, 44(1), 1-24.

Yacobi, H. (2009). Towards Urban Geopolitics, Geopolitics, 14: 576-581.

Yacobi, H. \& Pullan, W. (2014). The Geopolitics of Neighbourhood: Jerusalem's Colonial Space Revisited. Geopolitics, 19(3), 514-539.

Yiftachel, O. (2006). Ethnocracy: land and identity politics in Israel/Palestine. Philadelphia: University of Pennsylvania Press. 